\title{
Detection of Nitric Oxide in Plants by Electron Spin Resonance
}

\author{
Yang Cang Xu, Yuan Lin Cao, Ping Guo, Yi Tao, and Bao Lu Zhao
}

First, second, third, fourth, and fifth authors: Institute of Biophysics, Academia Sinica, Beijing 100101, China; and first author: Gansu Agricultural University, Lanzhou 730070, China. First and second authors contributed equally. Accepted for publication 28 December 2003.

\section{ABSTRACT}

Xu, Y. C., Cao, Y. L., Guo, P., Tao, Y., and Zhao, B. L. 2004. Detection of nitric oxide in plants by electron spin resonance. Phytopathology 94:402407.

Three methods to detect nitric oxide $\left(\mathrm{NO}^{\bullet}\right)$ are reported here. The first method was determining $\mathrm{NO}^{\bullet}$ in extracted plant tissue. $\mathrm{NO}^{\bullet}$ was trapped by spin trapping reagent containing diethyldithiocarbamate (DETC) and $\mathrm{FeSO}_{4}$, extracted by ethyl acetate, and determined with an electron spin resonance (ESR) spectrometer. The second method was indirectly determining $\mathrm{NO}^{\bullet}$ in live wheat leaves. Seedlings were cultured in a medium containing $\mathrm{FeSO}_{4}$, and the leaves were brushed by DETC. Then, the leaves were ground and the complex of (DETC) $)_{2}-\mathrm{Fe}^{2+}-\mathrm{NO}$ was extracted and determined with an ESR spectrometer. The third method was directly determining $\mathrm{NO}^{\bullet}$ in live wheat leaves. After treating plant materials as in the second method, part of the water in leaves was transpired, and the leaf disks were inserted directly into quartz tubes to determine $\mathrm{NO}^{\bullet}$ with an ESR spectrometer. The NO• scavenger 2-phenyl-4,4,5,5,-tetramethylimidazoline-1-oxyl 3-oxide (PTIO) decreased $\mathrm{NO}^{\bullet}$ signal detected either by an indirect or a direct method. This result indicates that both methods could detect $\mathrm{NO}^{\bullet}$ in the live plant. Using the first methods, we detected $\mathrm{NO}^{\bullet}$ change in wheat infected by Puccinia striiformis race CY22-2 pathogen (incompatible interaction) at different inoculation times, and it was found that the $\mathrm{NO}^{\bullet}$ content dramatically increased at $24 \mathrm{~h}$ postinoculation, quickly decreased at $48 \mathrm{~h}$, and increased again at $96 \mathrm{~h}$.

Additional keyword: free radicals.
In 1987, it was discovered that vascular endothelial cells could synthesize the free radical gas nitric oxide (NO*) (26), and $\mathrm{NO}^{\bullet}$ could act as a vasodilatory messenger (12). From then on, much attention was given to the study of $\mathrm{NO}^{\bullet}$ in biological systems (32), and many other important physiological functions of $\mathrm{NO}^{*}$ were discovered (21). In plants, although $\mathrm{NO}^{\bullet}$ research is more recent than in animals, mounting evidence suggests that $\mathrm{NO}^{\bullet}$ plays important roles in diverse physiological processes such as growth and development $(1,9,40)$, plant disease resistance $(6,8,25)$, abiotic stress $(17,19,38)$, and signal transmission (5-7).

Therefore, the direct detection of $\mathrm{NO}^{\bullet}$ has become attractive, especially in biological models. $\mathrm{NO}^{\bullet}$ detection assays include the following: (i) chemiluminescence detection using the reaction of $\mathrm{NO}^{\bullet}$ with ozone or luminol; (ii) fluorometry using a fluorescent $\mathrm{NO}^{\bullet}$ indicator; (iii) spectrophotometry using the formation of NOhemoglobin (NOHb); (iv) electron spin resonance (ESR) spectrometry using spin $\left(\mathrm{NO}^{\bullet}\right)$ traps such as $\mathrm{Hb}$, organic compounds, and iron-dithiocarbamate complexes; and (v) an electrochemical detection using microelectrodes specific to $\mathrm{NO}^{\bullet}$. Other indirect assays include spectrophotometry, fluorometry, and radiometry of stable biological metabolites of $\mathrm{NO}^{\bullet}$ or L-arginine such as nitrite, nitrate, and L-citrulline. We can apply any method of choice to detect and quantify $\mathrm{NO}^{\circ}$, but we need to choose the one that is most suitable for a specific purpose, because each method described previously has both merits and disadvantages. The chemiluminescence method, for instance, requires a gas-phase reaction of $\mathrm{NO}^{\bullet}$ with ozone. Although very sensitive and selective for $\mathrm{NO}^{*}$, the method required purging of aqueous samples with an

Corresponding author: B. L. Zhao; E-mail address: zhaobl@sun5.ibp.ac.cn

Publication no. P-2004-0224-01R

(c) 2004 The American Phytopathological Society inert gas to strip $\mathrm{NO}^{\bullet}$ into an analyzer. Therefore, it is incapable of monitoring intracellular $\mathrm{NO}^{*}$. The other chemiluminescence method with luminol has limitations for the functional analysis of $\mathrm{NO}^{*}$, such as the use of cytotoxic $\mathrm{H}_{2} \mathrm{O}_{2}$. Electrochemical sensing using microsensors provides in situ real-time detection of $\mathrm{NO}^{\circ}$. However, the only spatial information is directly at the electrode tip and is therefore influenced by the placement of the probe $(13,23,24)$.

ESR is a direct method to detect free radicals, and some efforts have been made to detect $\mathrm{NO}^{\bullet}(15,27)$. Mordvintcev et al. (22) employed the high affinity of $\mathrm{NO}^{\bullet}$ for transition metal ions to develop a method in which they used the complex of $\mathrm{Fe}^{2+}$ with diethyldithiocarbamate (DETC) to trap $\mathrm{NO}^{\bullet}$ and form a stable ternary complex (DETC) $)_{2}-\mathrm{Fe}^{2+}-\mathrm{NO}$. This ternary complex was then detected by ESR spectroscopy at $77 \mathrm{~K}$ (29). The spectral feature of the ternary complex (DETC) ${ }_{2}-\mathrm{Fe}^{2+}-\mathrm{NO}$ is an axial signal with an easily recognized hyperfine structure triplet at $\mathrm{g}_{\perp}=2.035$. However, the detection threshold is higher and the ternary complex (DETC) $)_{2}-\mathrm{Fe}^{2+}-\mathrm{NO}$ is not soluble in water. These drawbacks restrict this methods application in certain cases. Our laboratory improved this method by extracting the ternary complex (DETC) 2- $^{-}$ $\mathrm{Fe}^{2+}$-NO from the water phase into an organic phase. By this means, the detection threshold was improved to lower than $50 \mathrm{nM}$, which was 10 -fold more sensitive than the usual method. Using this method, the $\mathrm{NO}^{\bullet}$ in animal tissue extraction was successively detected at room temperature (36).

Reports on measuring $\mathrm{NO}^{*}$ by ESR in plants are very few. Mathieu et al. (20) detected the spectra of leghemoglobin-NO using ESR at $77 \mathrm{~K}$ in soybean nodules. To our knowledge, there is not an appropriate method to measure in vitro and in vivo $\mathrm{NO}^{\bullet}$ generated in plants by ESR at room temperature. The study reported here had two objectives: (i) modifying the method set up by our laboratory to detect $\mathrm{NO}^{\bullet}$ in plant tissue extraction at room temperature; and (ii) developing a method to detect $\mathrm{NO}^{\bullet}$ directly or indirectly in plants. 


\section{MATERIALS AND METHODS}

Plant materials. Wheat seeds (Triticum aestivum L. cv. Hanxuan 10) were sown in plastic pots and irrigated with Hoagland's solution. Seeds were allowed to germinate and develop in the greenhouse. The growth chamber was set at a relative humidity of 60 to $80 \%$, day/night temperatures of $25 / 20^{\circ} \mathrm{C}, 14 \mathrm{~h}$ photoperiod (600 $\mu \mathrm{mol}$ quanta $\mathrm{m}^{-2} \mathrm{~s}^{-1}$ photosynthetically active radiation) supplied by fluorescent lamps, and $10 \mathrm{~h}$ dark. Six-day-old seedlings were used as experimental materials. In the stripe rust disease infection experiment, wheat seedlings were inoculated with Puccinia striiformis Westend. race CY22-2 (provided by NorthWest Science-Technology University of Agriculture and Forestry) and incubated at $18 / 12^{\circ} \mathrm{C}$ (day/night).

Reagents and apparatus. DETC and PTIO (2-phenyl-4,4,5,5tetramethylimidazoline-1-oxyl 3-oxide) were purchased from Sigma. All other reagents were purchased in China and were analytical grade.

ESR experiments were performed on a spectrometer (200DSRC; Bruker Instruments, Germany). The (DETC) $)_{2}-\mathrm{Fe}^{2+}-\mathrm{NO}$ complex both in solution and in intact leaves was measured in a 2.5-mm (for solution) and 3.5-mm (for leaf disks) internal diameter quartz tube at $25^{\circ} \mathrm{C}$, respectively. For a control of (DETC) ${ }_{2}^{-}$ $\mathrm{Fe}^{2+}-\mathrm{NO}$ complex in frozen solution, the ESR spectrum was measured at $100 \mathrm{~K}$. The volume of organic solvent was $120 \mu \mathrm{l}$, and the height of leaf disks was $2 \mathrm{~cm}$. The conditions for measurement were as follows: X-band; $100 \mathrm{kHz}$ modulation with $3.2 \mathrm{G}$ amplitude; microwave power, $20 \mathrm{~mW}$; and central magnetic field $3,385 \mathrm{G}$, scan width $400 \mathrm{G}$, time constant $0.3 \mathrm{~s}$, and scan time $4 \mathrm{~min}$. The whole height of triplet hyperfine structure, namely the peak at $\mathrm{g}=2.035$ and its two neighbor peaks, was taken as relative intensity of the ESR signal.

Trapping NO N $^{\circ}$ in wheat seedling extract. Fresh leaf tissue samples $(0.5 \mathrm{~g})$ were ground in a chilled mortar with $1.0 \mathrm{ml}$ of $100 \mathrm{mM}$ phosphate buffer solution or $1.0 \mathrm{ml}$ of $100 \mathrm{mM}$ HEPES buffer solution. Both of them contained $0.32 \mathrm{M}$ sucrose, $0.1 \mathrm{mM}$ EDTA, and $5 \mathrm{mM}$ thioaethylenglycol. The homogenate was centrifuged at $13,201 \times g$ for $20 \mathrm{~min}\left(4^{\circ} \mathrm{C}\right)$. The supernatant contained $5.7 \mathrm{mg}$ of protein and was incubated with spin trapping reagent $\left(7.5 \mathrm{mM} \mathrm{FeSO}_{4}\right.$ and $\left.25 \mathrm{mM} \mathrm{DETC}\right)$. Then, $300 \mu \mathrm{l}$ of ethyl acetate was added to the mixture, shaken for $3 \mathrm{~min}$, and centrifuged at $13,201 \times g$ for $6 \mathrm{~min}$. The organic solvent layer was used to determine $\mathrm{NO}^{\bullet}$ on an ESR spectrometer.

Trapping $\mathrm{NO}^{\circ}$ in wheat seedlings. Six-day-old wheat seedlings were transferred to a culture medium containing $15 \mathrm{mM}$ $\mathrm{FeSO}_{4}$, and the leaves were brushed with $40 \mathrm{mM}$ DETC. After $24 \mathrm{~h}$, the leaf disks were divided into two parts. Part one, $0.5 \mathrm{~g}$ of leaf tissue was ground in a chilled mortar with $1.0 \mathrm{ml}$ of $100 \mathrm{mM}$ phosphate buffer solution ( $\mathrm{pH} 7.0$ ). After adding $300 \mu$ l of ethyl acetate to the homogenate, the mixture was shaken, centrifuged, and separated as described previously. The organic solvent layer was used to determine $\mathrm{NO}^{\bullet}$ on the ESR spectrometer (indirect method). Part two, $0.20 \mathrm{~g}$ leaves were treated in a $700 \mathrm{~W}$ microwave for $30 \mathrm{~s}$ to inactivate the enzymes in the leaves and kept at $40^{\circ} \mathrm{C}$ to partially dehydrate. Thereafter, the leaf disks were inserted directly into a quartz tube to determine $\mathrm{NO}^{\bullet}$ on an ESR spectrometer. The lost water ratio was calculated by measuring the weight of the leaves before and after the drying treatment.

Nitric oxide standard curve preparation. $\mathrm{NO}^{\bullet}$ gas was prepared as described by Zhao et al. (37) and its saturated concentration in water was calculated as described by Borutaite and Brow (2). The reaction mixture $(638 \mu \mathrm{l})$ contained $100 \mathrm{mM}$ phosphate buffer solution ( $\mathrm{pH} 7.0), 5.7 \mathrm{mg}$ of bovine serum albumin, $7.5 \mathrm{mM} \mathrm{FeSO}_{4}, 25 \mathrm{mM}$ DETC, and $\mathrm{H}_{2} \mathrm{O}$ or various concentration of $\mathrm{NO}^{\bullet}$ solution. Then, the procedures of incubation, extraction, shaking, separation, and measurement were done as described previously and an $\mathrm{NO}^{\bullet}$ standard curve was prepared.
Statistical analysis. Data were analyzed by analysis of variance and Student's $t$ test. Values are means of three independent experiments; standard deviations are indicated by error bars. At least 12 wheat seedlings were used per experiment.

\section{RESULTS}

Nitric oxide standard curve. Figure 1 shows an ESR spectrum where authentic nitric oxide gas was prepared by chemical process. The peak at $\mathrm{g}=2.035$ and its two neighbor peaks is attributed to the (DETC) $)_{2}-\mathrm{Fe}^{2+}-\mathrm{NO}$ complex. This triplet hyperfine structure is due to the interaction between the unpaired electron and the nitrogen nucleus of $\mathrm{NO}^{\circ}$. The spectra recorded in solution at room temperature have an isotropic spectrum as a result of rapid molecular motion. In addition to the ESR signal due to (DETC) ${ }_{2}$ $\mathrm{Fe}^{2+}-\mathrm{NO}$, the signal of DETC with copper is also presented $(16,30)$. It has been shown that the fourth peak at $\mathrm{g}=2.02$ is attributed to the complex of DETC and copper (39). In the process of preparing a nitric oxide standard curve, we also found that the height of the peak at $\mathrm{g}=2.02 \mathrm{did}$ not change with the increase of $\mathrm{NO}^{\circ}$ concentration (Fig. 1a and b). It is possible that this copper comes from reagents such as $\mathrm{FeSO}_{4}$, bovine serum albumin, or the phosphate buffer solution. However, the height of the triplet hyperfine structure increased linearly with the $\mathrm{NO}^{\bullet}$ concentration. After linear regression analysis, the correlation coefficient rate was 0.9952 (Fig. 1).

Detection of $\mathrm{NO}^{\bullet}$ in wheat seedlings extract. Typical ESR spectrometers have been developed to operate at microwave frequencies of approximately $9 \mathrm{GHz}$ (X-band). However, the presence of more water with a high dielectric constant in biological samples has hampered the development in this field. We used ethyl acetate to extract (DETC) $)_{2}-\mathrm{Fe}^{2+}-\mathrm{NO}$ complex from plant samples and then easily detected the complex spectra by ESR spectrometer (Fig. 2a), which was similar to that of control in Figure 1 and that reported in animal samples (36). This indicated that the signal came from (DETC) $)_{2}-\mathrm{Fe}^{2+}$-NO. HEPES buffer was often used as a solution ( $\mathrm{pH}$ 7.4) medium in animal tissue tests. We compared the effect of $100 \mathrm{mM}$ phosphate buffer solution $(\mathrm{pH} 7.0)$ and $100 \mathrm{mM}$ HEPES buffer solution ( $\mathrm{pH}$ 7.0) on the ESR signal in wheat leaf extract and found that ESR signal was higher in

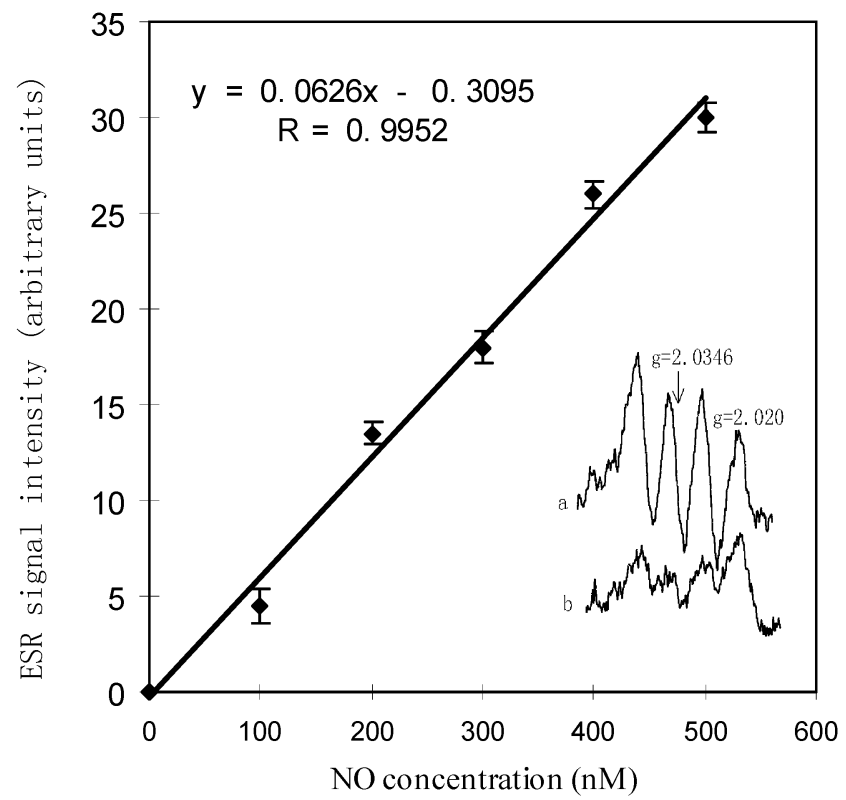

Fig. 1. Standard curve of the (DETC $)_{2}-\mathrm{Fe}^{2+}-\mathrm{NO}$ complex that was obtained by the reaction of $\mathrm{NO}^{\bullet}$ solution with (DETC) ${ }_{2}-\mathrm{Fe}^{2+}$. Insert is the electron spin resonance (ESR) spectra that represent $\mathrm{NO}^{*}$ concentrations at a, $500 \mathrm{nM}$ and b, $100 \mathrm{nM}$. 
phosphate buffer solution than in HEPES buffer solution (Fig. 3a and $b$ ). This indicated that phosphate buffer solution was more suitable for plant tissue. The effect of different temperatures also was studied and Figure $3 \mathrm{c}, \mathrm{d}$, and e show the $\mathrm{NO}^{\circ}$ content when the reaction mixture was incubated at 25,30 , and $37^{\circ} \mathrm{C}$, respectively, for $60 \mathrm{~min}$. The highest signal was detected at $30^{\circ} \mathrm{C}$ and this temperature was therefore best for plant tissue extraction. In addition, the effect of incubation periods was tested and it was found that $\mathrm{NO}^{\bullet}$ signal gradually increased with extension of the incubation period (Fig. $3 \mathrm{f}$ to h). The effect of $\mathrm{pH}$ was studied and it was found that the $\mathrm{NO}^{\bullet}$ content had no significant difference at pH 7.0 and 7.4 (Fig. 3i and j). Therefore, the optimum condition for determining $\mathrm{NO}^{\bullet}$ in plant tissue extract was when plant tissue was ground in phosphate buffer solution ( $\mathrm{pH} 7.0$ to 7.4) and the extract was incubated with trapping reagent containing $7.5 \mathrm{mM}$ $\mathrm{FeSO}_{4}$ and $25 \mathrm{mM} \mathrm{DETC}$ at $30^{\circ} \mathrm{C}$ for $60 \mathrm{~min}$.

Indirect detection of $\mathrm{NO}^{*}$ in live plants. After DETC and $\mathrm{FeSO}_{4}$ were absorbed by the leaves and roots of wheat seedlings, respectively, $\mathrm{NO}^{\bullet}$ produced in vivo was trapped by (DETC) $)_{2}-\mathrm{Fe}^{2+}$, and it then formed the (DETC) $)_{2}-\mathrm{Fe}^{2+}-\mathrm{NO}$ complex. Figure $2 \mathrm{~b}$

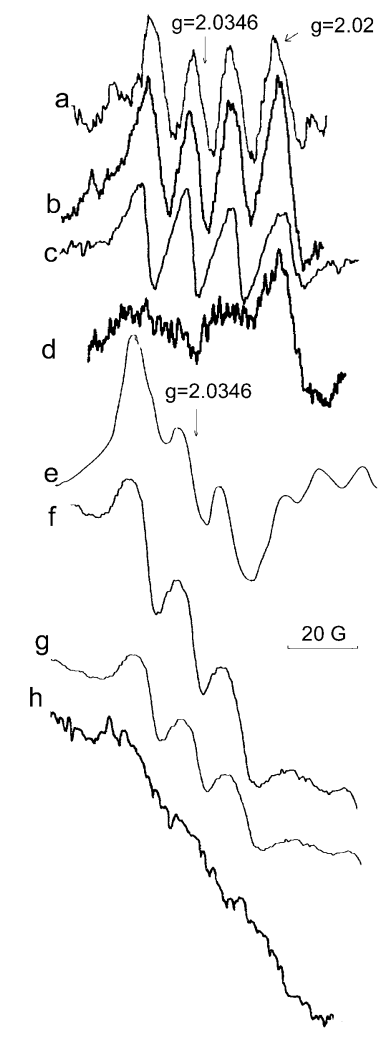

Fig. 2. The electron spin resonance (ESR) spectra of (DETC) $)_{2}-\mathrm{Fe}^{2+}$ $\mathrm{NO}$ detected by different methods. a, The (DETC) ${ }_{2}-\mathrm{Fe}^{2+}-\mathrm{NO}$ complex in the leaf homogenate was extracted by ethyl acetate and then measured on an ESR spectrometer. b, The (DETC) $)_{2}-\mathrm{Fe}^{2+}-\mathrm{NO}$ complex in live wheat leaves was extracted by ethyl acetate and then measured on an ESR spectrometer. c, 2-Phenyl-4,4,5,5,-tetramethylimidazoline-1-oxyl 3-oxide (PTIO; $0.5 \mathrm{mM}$ ) was supplied for $4 \mathrm{~h}$ prior to providing trapping reagent to wheat seedlings. d, PTIO $(1.0 \mathrm{mM})$ was supplied for $24 \mathrm{~h}$ prior to providing trapping reagent to wheat seedlings. The (DETC) $)_{2}-\mathrm{Fe}^{2+}-\mathrm{NO}$ signal was measured as in the procedure of b. e, (DETC) $)_{2}-\mathrm{Fe}^{2+}-\mathrm{NO}$ complex was obtained by the reaction of $\mathrm{NO}^{\bullet}$ solution with $(\mathrm{DETC})_{2}-\mathrm{Fe}^{2+}$, as described in the text, and $120 \mu \mathrm{l}$ of mixture solution was introduced into quartz tube and put into liquid nitrogen immediately, and was measured on an ESR spectrometer at $100 \mathrm{~K}$. f, The live wheat leaves $(0.2 \mathrm{~g})$ that contained (DETC $)_{2}-\mathrm{Fe}^{2+}-\mathrm{NO}$ complex were dried to lose water equal to approximately $30 \%$ of total weight, and the leaf disks were inserted directly into a quartz tube of $3.5-\mathrm{mm}$ internal diameter packed $2 \mathrm{~cm}$ in height and (DETC) $)_{2}-\mathrm{Fe}^{2+}-\mathrm{NO}$ signal was measured on an ESR spectrometer. g, PTIO $(0.5 \mathrm{mM})$ was supplied for $4 \mathrm{~h}$ prior to providing trapping reagent to wheat seedlings. h, PTIO $(1.0 \mathrm{mM})$ was supplied for $24 \mathrm{~h}$ prior to providing trapping reagent to wheat seedlings. The (DETC) $)_{2}-\mathrm{Fe}^{2+}-\mathrm{NO}$ signal was measured as in the procedure of $\mathbf{f}$. presents the spectrum which shows a ternary complex (DETC) $2_{2}^{-}$ $\mathrm{Fe}^{2+}$-NO with a hyperfine structure triplet at $\mathrm{g}=2.035$ with $\mathrm{a}_{\mathrm{N}}=$ $12.5 \mathrm{G}$. What is more, this spectrum was similar to that of the NO ${ }^{\bullet}$ standard curve (Fig. 1). In order to further ascertain the source of the signal, a PTIO (scavenger of $\mathrm{NO}^{\bullet}$ ) experiment was conducted. When $0.5 \mathrm{mM}$ PTIO was provided for $4 \mathrm{~h}$ before uptake of trapping reagent, the signal decreased significantly (Fig. 2c). When $1.0 \mathrm{mM}$ PTIO was provided for $24 \mathrm{~h}$ before uptake of trapping reagent, almost no signal could be detected (Fig. $2 \mathrm{~d}$ ). These results offer proof that the signals detected by ESR spectrometry came from $\mathrm{NO}^{\bullet}$ in the plant. Because $\mathrm{NO}^{\bullet}$ is a labile free radical and its half-life is very short (approximately $6 \mathrm{~s}$ ), the detected $\mathrm{NO}^{\bullet}$ content represents an accumulation of the trapped $\mathrm{NO}^{\circ}$ in leaves during $24 \mathrm{~h}$. Naturally, the shorter this period is, the lower the $\mathrm{NO}^{\bullet}$ content. In addition, the trapping reagent that entered the plant should be sufficient for trapping in vivo $\mathrm{NO}^{\circ}$. Incubating 6-day-old wheat seedlings with $15 \mathrm{mM} \mathrm{FeSO}_{4}$ and $40 \mathrm{mM}$ DETC for $6 \mathrm{~h}$ was enough for trapping in vivo $\mathrm{NO}^{\bullet}$ produced during $24 \mathrm{~h}$ (data not shown). DETC easily combines with $\mathrm{FeSO}_{4}$ to form a precipitating complex, which is difficult for plant absorption. Therefore, DETC and $\mathrm{FeSO}_{4}$ must be absorbed by different parts of the plant, such as roots and leaves.

Direct detection of $\mathrm{NO}^{*}$ in live plants. As mentioned previously, water in biological samples restricted ESR detection in certain cases. After DETC and $\mathrm{FeSO}_{4}$ were absorbed and the (DETC) $)_{2}-\mathrm{Fe}^{2+}-\mathrm{NO}$ complex accumulated to a specific level in the leaf, the intact leaf was heated by microwave for $30 \mathrm{~s}$ to inactivate in vivo enzyme activity and the leaves were kept at $40^{\circ} \mathrm{C}$ for various times to partially dehydrate them. Figure $2 \mathrm{f}$ shows the spectrum in intact leaves when the leaves lost water equal to approximately $30 \%$ of their total weight, which has similar spectrum parameters to that of Figure $2 \mathrm{e}$ in frozen solution at $100 \mathrm{~K}\left(\mathrm{~g}_{\perp}=\right.$ 2.035 with $\mathrm{a}_{\mathrm{N}}=12.5 \mathrm{G}$ ) and to the report by Goodman et al. (10). This indicates that the three peaks were also ascribed to (DETC) ${ }_{2}$ $\mathrm{Fe}^{2+}$-NO. The baseline of the spectrum was not parallel with the $x$ axis, similar to what had been found with that of nitric oxideleghemoglobin complex in intact soybean nodules (20). In addition, when the seedlings were treated by PTIO as described previously, the ESR signal in the intact leaf decreased significantly (Fig. 2f to h). This indicates that the signals detected in the intact leaf also came from $\mathrm{NO}^{*}$. Comparing with the spectra of Figure $2 \mathrm{a}$ to $\mathrm{d}$ in solution, the peaks in the spectra of Figure $2 \mathrm{e}$ to $\mathrm{h}$ in

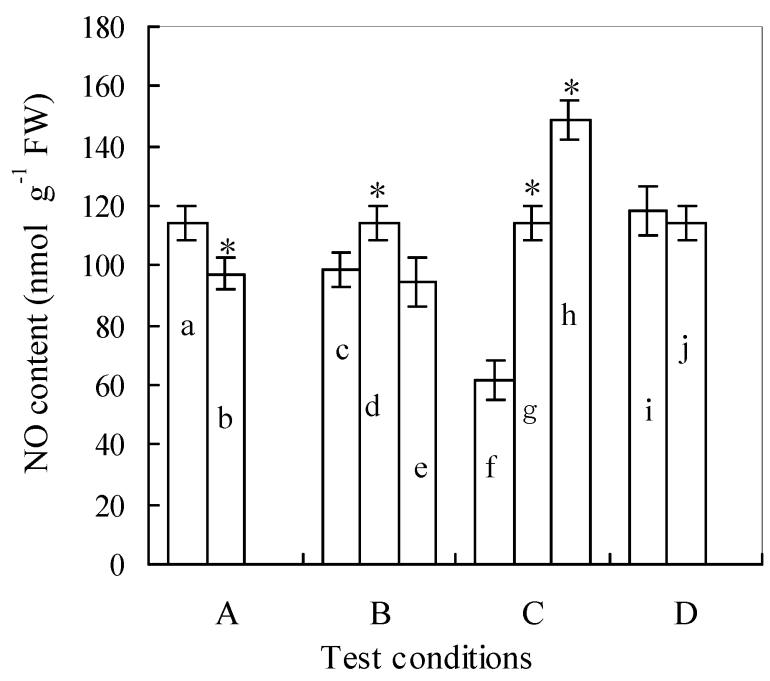

Fig. 3. The $\mathrm{NO}^{\bullet}$ content in wheat seedling extract under various experimental conditions: A, different media; $\mathbf{B}$, different temperatures; $\mathbf{C}$, different incubation periods; D, different $\mathrm{pH}$ levels; $\mathbf{a}$, phosphate buffer solution; b, HEPES buffer solution; c, $25^{\circ} \mathrm{C} ; \mathbf{d}, 30^{\circ} \mathrm{C} ; \mathbf{e}, 37^{\circ} \mathrm{C} ; \mathbf{f}, 30 \mathrm{~min} ; \mathbf{g}, 60 \mathrm{~min} ; \mathbf{h}, 90 \mathrm{~min}$; , $\mathrm{pH} 7.0$; and $\mathbf{j}, \mathrm{pH}$ 7.4. * Denotes significant differences from the first column of each group at the $5 \%$ confidence interval. 
frozen solution and leaves are broadening. When the excised leaves of wheat seedlings were kept at 0 to $4^{\circ} \mathrm{C}$ for $24 \mathrm{~h}$ after finishing the $40^{\circ} \mathrm{C}$ treatment, the $\mathrm{NO}^{\bullet}$ signal had no significant change (Fig. 4d). This indicated that the complex of (DETC) ${ }_{2}^{-}$ $\mathrm{Fe}^{2+}$-NO in intact leaves was relatively stable. In addition, when the leaves lost water equal to about 30,40 , and $50 \%$ of their total weight $(0.20 \mathrm{~g})$, the ESR signal slightly increased with the increase of lost water, but no statistically significant differences were observed (Fig. 4a to c). This indicated that when the leaves lost water equal to about 30 to $50 \%$ of their total weight, the effect of water in leaf on (DETC) $)_{2}-\mathrm{Fe}^{2+}$-NO signal was almost the same. Therefore, the $\mathrm{NO}^{\bullet}$ in leaf can be relatively constantly detected by this method under the above conditions. When the leaves lost water equal to less than $20 \%$ of their total weight, the ESR spectrometer could scarcely detect the (DETC) $)_{2}-\mathrm{Fe}^{2+}-\mathrm{NO}$ signal at room temperature (data not shown).

Changes of $\mathrm{NO}^{\bullet}$ contents in wheat seedlings infected by $P$. striiformis at different times. The stripe rust (or yellow rust) caused by $P$. striiformis is a serious disease of wheat in many areas of the world. It has been shown that $\mathrm{NO}^{\bullet}$ plays an important role in plant disease resistance $(6,8,25)$. Wheat seedlings infected by CY22-2 show an incompatible interaction (identified by NorthWest Science-Technology University of Agriculture and Forestry). We found no stripe rust symptoms on leaves after inoculation (data not shown). When monitoring $\mathrm{NO}^{\bullet}$ contents in wheat seedlings infected by CY22-2 at different inoculation times, it was found that the $\mathrm{NO}^{\bullet}$ content dramatically increased at $24 \mathrm{~h}$, quickly decreased at $48 \mathrm{~h}$, and increased again at $96 \mathrm{~h}$ (Table 1). These results suggest that $\mathrm{NO}^{\bullet}$ may play an important role in wheat stripe rust disease resistance. The mechanism is under study in our laboratory.

\section{DISCUSSION}

In general, ESR is considered the most direct and efficient technique available for detection and measurement of free radicals. Spin trapping is a common technique to detect nitric oxide free radicals. DETC, MGD ( $N$-methyl-D-glucamine dithiocarbamate), and DTCS (dithiocarboxy sarcosine) are often used as trapping reagents $(31,35)$. They have been applied extensively to detect $\mathrm{NO}^{\bullet}$ produced in animal systems. However, the concentration of $\mathrm{NO}^{\bullet}$ generated in some biological systems is too low to be detected. In addition, the water in biological samples also affects

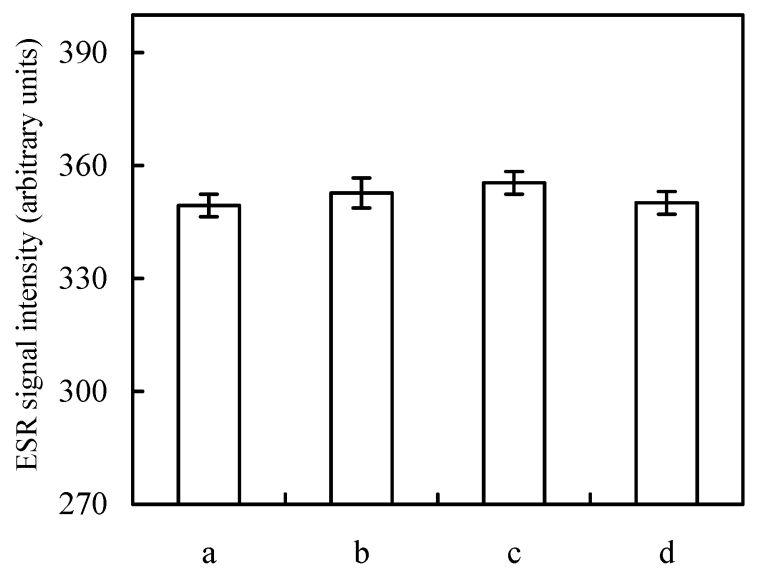

Test conditions

Fig. 4. The electron spin resonance (ESR) signal intensity in intact leaves under various experimental conditions. Excised leaves lost water to about a, $30 \%$; b, $40 \%$; and c, $50 \%$ of their total weight by keeping the leaves at $40^{\circ} \mathrm{C}$ for various times. d, After the treatment of $\mathbf{a}$, excised leaves were kept at 0 to $4^{\circ} \mathrm{C}$ for another $24 \mathrm{~h}$
ESR detection. These features impair the sensitivity of ESR and restrict its application. (DETC) $)_{2}-\mathrm{Fe}^{2+}-\mathrm{NO}$ is a hydrophobic complex that can be extracted by organic solvents. Our laboratory used ethyl acetate as an extract solvent to concentrate $\mathrm{NO}^{\bullet}$ from tissue and successively detected $\mathrm{NO}^{\bullet}$ content in animal tissue (36). $\mathrm{NO}^{\bullet}$ is generated almost exclusively by nitric oxide synthase (NOS) in animal cells. However, $\mathrm{NO}^{\bullet}$ is produced in many ways by plant cells (33). What is more, there are several differences in $\mathrm{NO}^{\circ}$ metabolism between animal tissue and plant tissue. Therefore, the experimental conditions tested here in plants such as temperature, extract buffer solution, $\mathrm{pH}$, and so on were different from those employed in animals. In this study, we improved the method to measure $\mathrm{NO}^{\bullet}$ content in plant tissue extract. The optimum condition of determining $\mathrm{NO}^{\bullet}$ concentration in plant tissue extract was when the plant tissue was ground in phosphate buffer solution ( $\mathrm{pH} 7.0$ to 7.4) and the extract was incubated with trapping reagent containing $7.5 \mathrm{mM} \mathrm{FeSO}_{4}$ and $25 \mathrm{mM}$ DETC at $30^{\circ} \mathrm{C}$ for $60 \mathrm{~min}$. Previous evidence indicates that NOS exists in plants $(28,33)$ and that the main pathway of producing $\mathrm{NO}^{\bullet}$ in the plant was via nitrate reductase (NR) $(14,18,34)$. The optimum $\mathrm{pH}$ of both NOS and NR was about $7.4(3,8)$. Our results show that there was no significant difference in $\mathrm{NO}^{\circ}$ content in wheat leaves extract at $\mathrm{pH} 7.0$ and at $\mathrm{pH}$ 7.4. This possibly relates to the many means of $\mathrm{NO}^{\bullet}$ formation in plants (33) and the complex components in the extraction. Because cell structure was destroyed during the extraction and the physiological status was changed, $\mathrm{NO}^{\bullet}$ detected by this method represents the $\mathrm{NO}^{\bullet}$ level in the extracted plant tissue but not in the live plant. However, it is still a useful method for the study of $\mathrm{NO}^{\bullet}$ in plants, such as $\mathrm{NO}^{\bullet}$ source in plant.

In order to detect $\mathrm{NO}^{\bullet}$ in live plants, the trapping reagent must enter into the foliage. However, DETC easily combines with $\mathrm{FeSO}_{4}$ to form hydrophobic complexes, which was difficult for plant absorption. Therefore, DETC and $\mathrm{FeSO}_{4}$ must be absorbed by different parts of plants, such as roots and leaves. The complex of (DETC) $)_{2}-\mathrm{Fe}^{2+}-\mathrm{NO}$ in leaf was relatively stable at 0 to $4^{\circ} \mathrm{C}$ (Fig. $4 d)$, which was similar to the complex in ethyl acetate solvent (36).

When (DETC) $)_{2}-\mathrm{Fe}^{2+}-\mathrm{NO}$ accumulates to a certain level in the leaf, the complex can be extracted by ethyl acetate and then measured on an ESR spectrometer (indirect method) or it can be measured directly on an ESR spectrometer (direct method). Because the water in the leaf absorbs microwaves, the (DETC) $)_{2}-\mathrm{Fe}^{2+}-\mathrm{NO}$ signal in fresh leaves cannot be detected by the direct method at room temperature. Therefore, part of the water in fresh leaves must be eliminated. Theoretically speaking, more (DETC) $)_{2}-\mathrm{Fe}^{2+}-$ NO signal should be detected as leaves lose water. However, if all water in leaves is transpired, it is difficult for these completely dehydrated leaves to be correctly inserted into quartz tube. The lost water rate was related to plant species, plant organ, growth status, and other factors. For 6-day-old wheat seedlings, the NO ${ }^{\bullet}$ signal was relatively stable when leaves lost water of about 30 to $50 \%$ of their total weight (Fig. 4). The baseline of the spectrum was not parallel with the $x$ axis (Fig. $2 \mathrm{f}$ to h). Probably, $\mathrm{Fe}^{3+}$ (as ferritin) and $\mathrm{Cu}^{2+}$ (as mononuclear complexes) produce absorptions in this region. The broadened peaks in these spectra could be explained by restricted molecular motion of the (DETC) $)_{2}-\mathrm{Fe}^{2+}-\mathrm{NO}$ complex. Although the direct method has some shortfalls, it was superior to the indirect method. First, the procedure was simple, which reduces test error caused by the experimenter. Second, the experi-

TABLE 1. NO• contents in wheat seedlings infected by CY22-2 at different inoculation times

\begin{tabular}{|c|c|c|c|c|}
\hline \multirow[b]{2}{*}{ Pathogen } & \multicolumn{4}{|c|}{$\mathrm{NO}^{\bullet}$ content ( $\mathrm{nmol} \mathrm{g}^{-1}$ free weight) } \\
\hline & $0 \mathrm{~h}$ & $24 \mathrm{~h}$ & $48 \mathrm{~h}$ & $96 \mathrm{~h}$ \\
\hline CY22-2 & $114.3 \pm 5.6$ & $256.3 \pm 6.2$ & $119.8 \pm 7.5$ & $326.5 \pm 6.3$ \\
\hline
\end{tabular}


mental materials of $2 \mathrm{~cm}$ long was enough for plant disks in quartz tube, so the $\mathrm{NO}^{\bullet}$ contents in different parts of plant, such as roots, shoots, leaf, flower, pathogen-infected areas, or noninfected areas, could be analyzed directly. The $\mathrm{NO}^{\bullet}$ scavenger PTIO decreased the ESR signal detected either by the indirect or by the direct method (Fig. 2). This indicated that both the indirect method and the direct method could detect $\mathrm{NO}^{\bullet}$ in live plants.

Previous evidence showed that $\mathrm{NO}^{\bullet}$ plays an important role in plant disease resistance $(6,8,25)$. We found the $\mathrm{NO}^{\bullet}$ content in wheat leaves infected by $P$. striiformis race CY22-2 show an updown-up pattern of variation (Table 1). As described previously, $\mathrm{NO}^{\bullet}$ has many means of formation in plants (33). Part of the NO may be produced by $\operatorname{NOS}(11,28,38)$; part of the $\mathrm{NO}^{\bullet}$ was possibly produced by the way of NR $(14,18,34)$; part of the NO ${ }^{\bullet}$ may come from carotenoids pathway (4); and part of the $\mathrm{NO}^{\bullet}$ was possibly produced by a chemical pathway, such as the change of $\mathrm{pH}$ (33). It is possible that different routes to $\mathrm{NO}^{\bullet}$ formation have different sensitivity to biotic and abiotic stresses. When wheat seedlings were infected by $P$. striiformis race CY22-2, the rapid response route was probably activated first and then the slow response was activated, so the $\mathrm{NO}^{\bullet}$ content shows two phases of increase (Table 1). Besides the signal function, $\mathrm{NO}^{\bullet}$ also acts as a toxic molecule. In evolution, plants potentially developed some mechanisms to inhibit $\mathrm{NO}^{\bullet}$ content increases. This is possibly the reason for initial $\mathrm{NO}^{\bullet}$ content increase followed by a decrease after some time (Table 1).

In summary, these methods may not only be applied to phytopathological studies but also help us to understand pathophysiological processes, especially $\mathrm{NO}^{\bullet}$ roles in the plant disease response.

\section{ACKNOWLEDGMENTS}

We thank R. L. Jing from the Chinese Academy of Agricultural Science for providing wheat seeds and the National Science Foundation of China (30070196) for financial support.

\section{LITERATURE CITED}

1. Beligni, M. V., and Lamattina, L. 2000. Nitric oxide induces seed germination and de-etiolation, and inhibits hypocotyl elongation, three lightinducible responses in plants. Planta 210:215-221.

2. Borutaite, V., and Brow, G. C. 1996. Rapid reduction of nitric oxide by mitochondria, and reversible inhibition of mitochondrial respiration by nitric oxide. Biochem. J. 315:295-299.

3. Chen, W., and Zhang, D. Y. 1980. The extraction, measurement and purification of nitrate reductase in plant. Plant Physiol. Commun. 4:4547.

4. Cooney, R. V., Harwood, P. J., Custer, L. J., and Franke, A. A. 1994. Light-mediated conversion of nitrogen dioxide to nitric oxide by carotenoids. Environ. Health Perspect. 102:460-462.

5. Dangl, J. 1998. Plants just say NO to pathogens. Nature 394:525-527.

6. Delledonne, M., Xia, Y., Dixon, R. A., and Lamb, C. 1998. Nitric oxide functions as a signal in plant disease resistance. Nature 394:586-588.

7. Durner, J., and Klessig, D. F. 1999. Nitric oxide as a signal in plants. Curr. Opin. Plant Biol. 2:369-374.

8. Durner, J., Wendehenne, D., and Klessig, D. F. 1998. Defense gene induction in tobacco by nitric oxide, cyclic GMP, and cyclic ADP-ribose. Proc. Natl. Acad. Sci. USA 95:10328-10333.

9. Ferrer, M. A., and Ros-Barcelo, A. 1999. Differential effects of nitric oxide on peroxidase and $\mathrm{H}_{2} \mathrm{O}_{2}$ production by the xylem of Zinnia elegans. Plant Cell Environ. 223:891-897.

10. Goodman, B. A., Raynor, J. B., and Symons, M. C. R. 1969. Electron spin resonance of bis (N,N-diethylthiocarbamato)-nitrosyl iron. J. Chem. Soc. A:2572-2575.

11. Guo, F. Q., Okamoto, M., and Crawford, N. M. 2003. Identification of a plant nitric oxide synthase gene involved in hormonal signaling. Science 302:100-103.

12. Ignarro, L. J., Buga, G. M., Wood, K. S., and Byrns, R. E. 1987. Endothelium-derived relaxing factor produced and released from artery and vein is nitride oxide. Proc. Natl. Acad. Sci. USA 84:92659629.
13. Ishida, Y., Hashimoto, M., Fukushima, S., Masumura, S., Sasaki, T., Nakayama, K., Tamura, K., Murakami, E., Isokawa, S., and Momose, K. 1996. A nitric oxide-sensitive electrode: Requirement of lower oxygen concentration for detection nitric oxide from the tissue. J. Pharmacol. Toxicol. Methods 35:19-24.

14. Klepper, L. 1990. Comparison between $\mathrm{NO}_{\mathrm{X}}$ evolution mechanisms of wild-type and $\mathrm{nr}_{1}$ mutant soybean leaves. Plant Physiol. 93:26-32.

15. Kosaka, H., Watanabe, M., Yoshihara, H., Harada, N., and Shiga, T. 1992. Detection of nitric oxide production in lipopolysaccharide-treated rats by ESR using carbon monoxide hemoglobin. Biochem. Biophys. Res. Commun. 184:1119-1124.

16. Kubrina, L. N., Caldwell, W. S., Mordvintcev, P. I., Malenkova, I. V., and Vanin, A. F. 1992. EPR evidence for nitric oxide production from guanidine nitrogen of L-arginine in animal tissues in vivo. Biochim. Biophys. Acta 1099:233-237.

17. Leshem, Y. Y., and Harammaty, E. 1996. The characterization and contrasting effects of the nitric oxide free radical in vegetative stress and senescence of Pisum sativum Linn. foliage. J. Plant Physiol. 148:258263.

18. Mallick, N., Rai, L. C., Mohn, F. H., and Soeder, C. J. 1999. Studies on nitric oxide (NO) formation by the green alga scenedesmus obliquus and the diazotrophic cyanobacterium anabaena doliolum. Chemosphere 39:1601-1610.

19. Mata, C. G., and Lamattina, L. 2001. Nitric oxide induces stomatal closure and enhances the adaptive plant responses against drought stress. Plant Physiol. 126:1196-1204.

20. Mathieu, C., Moreau, S., Frendo, P., and Puppo, A., and Davies, J. M. 1998. Direct detection of radicals in intact soybean nodules: Presence of nitric oxide-leghemoglobin complexes. Free Radic. Biol. Med. 24:12421249.

21. Moilanen, E., and Vapaatalo, H. 1995. Nitric oxide in inflammation and immune response. Ann. Med. 27:359-367.

22. Mordvintcev, P., Musch, A., Busse, R., and Vanin, A. 1991. On-line detection of nitric oxide formation in liquid aqueous phase by electron paramagnetic resonance spectroscopy. Anal. Biochem. 199:142-146.

23. Nagano, T., and Yoshimura, T. 2002. Bioimaging of nitric oxide. Chem. Rev. 102:1235-1269.

24. Nakatsubo, N., Kojima, H., Kikuchi, K., Nagoshi, H., Hirata, Y., Maeda, D., Imai, Y., Irimura, T., and Nagano, T. 1998. Direct evidence of nitric oxide production from bovine aortic endothelial cells using new fluorescence indicators: diaminofluoresceins. FEBS Letts. 427:263266.

25. Noritake, T., Kawakita, K., and Doke, N. 1996. Nitric oxide induces phytoalexin accumulation in potato tuber tissue. Plant Cell Physiol. 37:113-116.

26. Palmer, R. M. J., Ferrige, A. G., and Moncada, S. 1987. Nitric oxide release accounts for the biological activity of endothelium-derived relaxing factor. Nature 327:524-526.

27. Pronai, L., Ichimori, K., Nozaki, H., Nakazawa, H., Okino, H., Carmichael, A. J., and Arroyo, C. M. 1991. Investigation of the existence and biological role of L-arginine/nitric oxide pathway in human platelets by spin-trapping/EPR studies. Eur. J. Biochem. 202:923-930.

28. Ribeiro, E. A., Jr., Cunha, F. Q., Tamashiro, W. M. S. C., and Martins, I. S. 1999. Growth phase-dependent subcellular localization of nitric oxide synthase in maize cells. FEBS Letts. 445:283-286.

29. Ryan, T. P., Miller, D. M., and Aust, S. D. 1993. The role of metals in the enzymatic and nonenzymatic oxidation of epinephrine. J. Biochem. Toxicol. 8:33-39.

30. Tominaga, T., Sato, S., Ohnishi, T., and Ohnishi, S. T. 1993. Potentiation of nitric oxide formation following bilateral carotid occlusion and focal cerebral ischemia in the rat: In vivo detection of the nitric oxide radical by electron paramagnetic resonance spin trapping. Brain Res. 614:342346.

31. Tsuchiya, K., Takasugi, M., Minakuch, K., and Fukuzawa, K. 1996. Sensitive quantitation of nitric oxide by EPR spectroscopy. Free Radic. Biol. Med. 21:733-737.

32. Vincent, S. R., and Hope, B. T. 1992. Neurons that say NO. Trends Neurosci. 15:108-110.

33. Wojtaszek, P. 2000. Nitric oxide in plants to no or not to no. Phytochemistry $54: 1-4$.

34. Xu, Y. C., and Zhao, B. L. 2003. The main origin of endogenous NO in higher non-leguminous plants. Plant Physiol. Biochem. 41:833-838.

35. Yoshimura, T., Yokoyama, H., Fujii, S., Takayama, F., Oikawa, K., and Kamada, H. 1996. In vivo EPR detection and imaging of endogenous nitric oxide in lipopolysaccharide-treated mice. Nat. Biotechnol. 14:992994.

36. Zhang, D., Xiong, J., Hu, J., and Zhao, B. 2001. Improved method to detect nitric oxide in biology systems. Appl. Magn. Reson. 20:345-356.

37. Zhao, B. L., Shen, J. G., Li, M., Li, M. F., Wan, Q., and Xin, W. J. 1995. Scavenging effect of chinonin on NO and oxygen free radicals and its 
protective effect on the myocardium from the injury of ischemia-reperfusion. Biochim. Biophys. Acta 1315:131-137.

38. Zhao, Z., Chen, G., and Zhang, C. 2001. Interaction between reactive oxygen species and nitric oxide in drought-induced abscisic acid synthesis in root tips of wheat seedlings. Aust. J. Plant Physiol. 28:10551061.
39. Zhou, G., Zhao, B., Hou, J., Li, M., Chen, C., and Xin, W. 1999. Detection of nitric oxide in tissue by spin trapping EPR spectroscopy and triacetylglycerol extraction. Biotechnol. Tech. 13:507-511.

40. Zottini, M., Formentin, E., Scattolin, M., Carimi, F., Schiavo, F. L., and Terzi, M. 2002. Nitric oxide affects plant mitochondrial functionality in vivo. FEBS Letts. 515:75-78. 